\title{
Identification of novel cps locus polymorphisms in nontypable group B Streptococcus
}

\author{
Correspondence \\ Lawrence C. Paoletti \\ Ipaoletti@channing.harvard.edu
}

Received 19 July 2005

Accepted 7 February 2006

\author{
Srinivas V. Ramaswamy, ${ }^{1}$ Patricia Ferrieri, ${ }^{2}$ Lawrence C. Madoff, ${ }^{1}$ \\ Aurea E. Flores, ${ }^{2}$ Nikhil Kumar, ${ }^{3}$ Hervé Tettelin ${ }^{3}$ and Lawrence C. Paoletti ${ }^{1}$ \\ ${ }^{1}$ Channing Laboratory, Department of Medicine, Brigham and Women's Hospital, Harvard \\ Medical School, Boston, MA 02115, USA \\ ${ }^{2}$ Departments of Laboratory Medicine and Pathology and Pediatrics, University of Minnesota \\ Medical School, Minneapolis, MN 55455, USA \\ ${ }^{3}$ The Institute for Genomic Research, 9712 Medical Center Drive, Rockville, MD 20850, USA
}

Group B Streptococcus (GBS) is an important pathogen responsible for a variety of diseases in newborns and the elderly. A clinical GBS isolate is considered nontypable (NT) when serological methods fail to identify it as one of nine known GBS serotypes. Eight clinical isolates (designated A1-A4, B1-B4) showed PFGE profiles similar to that of a GBS serotype $V$ strain expressing R1, R4 surface proteins. These unique isolates were further characterized by immunologic and genetic methods. Rabbit sera to isolates $\mathrm{A} 1$ and $\mathrm{A} 2$ reacted weakly with concentrated $\mathrm{HCl}$ extracts of A1-A4 isolates, but not with those of B1-B4 isolates. In addition, a type $\mathrm{V}$ capsular polysaccharide (CPS) inhibition ELISA revealed that cell wall extracts from isolates A1-A4, but not from B1-B4, expressed low but measurable amounts of type V CPS. Molecular serotyping with PCR analysis showed that all eight isolates contained a type V-specific CPS gene (cpsO) and harboured the gene encoding the surface protein Alp3. Multilocus sequence typing identified isolate $\mathrm{A} 1$ as belonging to a new sequence type (ST) designated ST-173, whereas the other seven isolates keyed to ST-1. Sequencing of the 18 genes (17 $736 \mathrm{bp)}$ ) in the cps locus showed that each NT isolate harboured one to three unique polymorphisms, and also identified an IS1381 element in $c p s E$ of the B4 isolate. Collectively, genetic and immunologic analyses revealed that these NT isolates expressing R1, R4 proteins have a genetic profile consistent with that of type V, an emergent, antigenically diverse and increasingly prevalent GBS serotype.

\section{INTRODUCTION}

Streptococcus agalactiae or group B Streptococcus (GBS) is the most common cause of neonatal sepsis and meningitis, and is increasingly recognized as an important cause of invasive disease in non-pregnant adults and immunocompromised individuals. It is an opportunistic pathogen, and can be isolated from the genitourinary tracts of about $35 \%$ of healthy adult women (Bliss et al., 2002). Although the use of intrapartum antibiotic prophylaxis has considerably reduced the incidence of neonatal GBS disease, vaccination offers the best long-term solution to prevention of disease, and, towards that end, considerable progress has been made in the development of GBS vaccines (Maione et al., 2005; Paoletti \& Kasper, 2003; Ramaswamy et al., 2004).

Abbreviations: CPS, capsular polysaccharide; GBS, Group B Streptococcus; MLST, multilocus sequence typing; NT, nontypable; ST, sequence type.

The GenBank/EMBL/DDBJ accession numbers for the sequences reported in this paper are D0359707-D0359714.
Capsular polysaccharides (CPSs) are major virulence factors and the main components of glycoconjugate vaccines. In addition, these surface carbohydrates provide useful epidemiologic markers, as GBS isolates are serotyped on the basis of their CPS antigens; nine distinct serotypes ( $\mathrm{Ia}, \mathrm{Ib}$, and II-VIII) have thus far been described. The prevalence of GBS serotypes fluctuates over time and by geographic location (Le Thomas-Bories et al., 2001). Although serotype III strains are responsible for the majority of cases of neonatal meningitis worldwide, serotype $\mathrm{V}$ strains are isolated with increased frequency from all age groups within a population, and an estimated $24-31 \%$ of the cases of invasive GBS disease in non-pregnant adults in the USA are caused by this serotype (Blumberg et al., 1996; Farley, 2001; Le ThomasBories et al., 2001).

Isolates without identifiable CPS by the standard Lancefield serotyping method are considered nontypable (NT). NT isolates may account for up to $4 \%$ of all GBS isolates (Ferrieri et al., 1997), but account for up to $12 \%$ in collections studied in some laboratories (Palacios et al., 1997). The extent of sequence variation in the cps genes of clinical 
isolates within a serotype, and among different serotypes, has not been well studied. It has been observed that closely and distantly related clones of GBS may share the genes encoding a specific CPS, suggesting that capsule switching may occur in GBS (Davies et al., 2004).

Most NT isolates express surface proteins: alpha and beta components of the $\mathrm{C}$ protein or one or more of the $\mathrm{R}$ protein antigens, Rib, and Alp1-4 proteins (Benson et al., 2002; Kong et al., 2002b). These isolates can be genotyped and distinguished by PFGE and by the expressed surface-protein antigens (Ferrieri et al., 1997; Ferrieri \& Flores, 1997; Sellin et al., 2000). The $\mathrm{C}$ proteins were recognized by Lancefield as protective determinants found in GBS of serotypes Ia and Ib (reviewed by Lindahl et al., 2005). One of the C proteins, the beta $\mathrm{C}$ protein, binds to human IgA and is found mainly in serotype Ib GBS. The other $\mathrm{C}$ protein, the alpha $\mathrm{C}$ protein, has been recognized to be the prototype for a family of proteins (alpha-like proteins) that is found in most GBS and includes Rib and Alp1-4. The protein Rib is most frequently associated with type II and III GBS, while Alp1 is found frequently in serotype Ia GBS, and Alp3 most frequently in serotype V. R proteins (R1-4) have been defined immunologically on the basis of cross-reactivity among streptococcal strains, but are less well defined at the genetic level (Flores \& Ferrieri, 1989), except that the gene for the R4 protein has been cloned and is identical to the Rib gene (Smith et al., 2004). The other R proteins appear to be closely related or identical to members of the Alp family. While certain surface proteins tend to be associated with certain capsular types, there is no genetic linkage, and numerous exceptions occur (Tettelin et al., 2005).

Herein we performed immunologic and genetic analysis of eight clinical isolates that were NT, but expressed R1, R4 proteins associated with serotype $\mathrm{V}$. We hypothesized that these isolates might harbour genetic changes in the cps locus that lead to an NT phenotype. Sequencing of the 18 genes in the $c p s$ locus revealed unique mutations in each of the eight GBS isolates.

\section{METHODS}

Bacterial isolates. Eight colonizing (vaginal or rectal) GBS isolates designated A1-A4 and B1-B4 were collected as part of an active GBS surveillance study between January 1994 and January 1996. They did not express any definable CPS by routine doubleimmunodiffusion in an agarose serotyping assay. Isolates A1-A4 and B1-B3 were isolated from pregnant and non-pregnant women in Seattle, WA, USA, and isolate B4 was a vaginal isolate recovered from a woman in Pittsburgh, PA, USA. These isolates expressed R1, R4 surface proteins and had a PFGE banding profile identical to that of a prototype V/R1, R4 isolate. A prototype V strain (SS1169) was used as a control for several experiments. In addition, four more serotype $\mathrm{V}$ clinical isolates were used in comparative experiments. Two of these, 17 and 19, were invasive isolates from Houston, TX, USA (collected in 2001 and 2003, respectively), 26 was a vaginal isolate from Pittsburgh (collected in 2002), and 10 was a vaginal isolate from Minneapolis, MN, USA (collected in 1981). All GBS isolates were grown at $37^{\circ} \mathrm{C}$ in Todd-Hewitt broth (THB; Difco Laboratories) and modified with $2 \%$ glucose and $1.5 \%$ sodium phosphate for experiments designed to upregulate CPS production.

Double-immunodiffusion reactions. Five millilitres of $7 \mathrm{~h} \mathrm{cul}-$ tures were inoculated into $50 \mathrm{ml}$ modified THB and incubated overnight at $37^{\circ} \mathrm{C}$. Cells were extracted with hot $0 \cdot 2 \mathrm{M} \mathrm{HCl}$, concentrated $5 \times$ in a Microcon YM-10 centrifugal filter device (Amicon) and serotyped by double immunodiffusion in agarose using type $\mathrm{V}$ monospecific antisera (Slotved et al., 2002). Isolates A1 and A2 were used to immunize rabbits designated R-41 and R-43, respectively. Antisera obtained from the two rabbits, along with hyperimmune rabbit antiserum to prototype serotype $\mathrm{V}$, were used in double-immunodiffusion reactions in agarose (Ferrieri \& Flores, 1997). These reactions were also used to identify surface-protein antigens (Flores \& Ferrieri, 1989).

Inhibition ELISA. An inhibition ELISA was performed to assess the relative amounts of CPS produced by the eight isolates. All eight isolates were grown in modified THB to an $\mathrm{OD}_{650}$ of $0 \cdot 3$. The CPSs were extracted with mutanolysin (Ferrieri \& Flores, 1997). Briefly, the harvested cell pellet was washed twice with $50 \mathrm{mM}$ sodium phosphate buffer $(\mathrm{pH} \mathrm{7 \cdot 0)}$ ) and then resuspended in $750 \mu$ of $40 \%$ sucrose in $50 \mathrm{mM}$ sodium phosphate buffer $(\mathrm{pH} 7 \cdot 0)$. To each sample, $250 \mu \mathrm{l}$ mutanolysin $\left(1 \mathrm{mg} \mathrm{ml}^{-1}\right.$ in $50 \mathrm{mM}$ sodium phosphate buffer, $\mathrm{pH} 7 \cdot 0$ ) was added, followed by incubation at $37^{\circ} \mathrm{C}$ overnight with end-over-end mixing. Protoplasts and cell debris were removed by centrifugation, and the supernatants containing CPS were transferred to fresh tubes and stored at $-20{ }^{\circ} \mathrm{C}$. The ELISA plates were coated with type V CPS-human serum albumin conjugate, as described previously (Baker et al., 2004). Mutanolysin-extracted CPS was added as an inhibitor, and threefold serial dilutions were made with PBS. Rabbit serum (diluted 1:200 000) containing antibodies raised against type V-tetanus toxoid conjugated vaccine was added. After incubation, a goat anti-rabbit IgG-alkaline phosphatase conjugated secondary antibody (diluted $1: 2000$ ) was added to the plates, and the reaction plates were read in a Biotek microtitre plate reader (Biotek Instruments). The experiments were done in duplicate for all the isolates, and the results from the ELISA plates were averaged. Relative percentage inhibition of each preparation was determined by comparison to that obtained with purified type V CPS, which resulted in complete $(100 \%)$ inhibition. Percentage inhibition was calculated as $\left[\left(A_{\text {no inhibitor }}-A_{\text {test }}\right) / A_{\text {no inhibitor }}\right] \times 100$. The concentration of type $\mathrm{V}$ CPS in each preparation was determined by multiplying the amount of purified type V CPS that resulted in $60 \%$ inhibition (linear portion of the standard curve) by the dilution of the extract that resulted in the same degree of inhibition.

PFGE. A rapid PFGE assay was performed on isolates according to a published protocol (Benson \& Ferrieri, 2001; Fasola et al., 1993; Tenover et al., 1995). Briefly, bacteria were embedded in agarose plugs and treated with mutanolysin and proteinase $\mathrm{K}$ to lyse the cell wall and precipitate the proteins. The DNA was digested in situ with SmaI restriction enzyme, and the resulting fragments were resolved by PFGE. The PFGE profiles of the isolates were compared visually to the band profiles of the prototype isolate using the criteria of Tenover et al. (1995).

Multilocus sequence typing (MLST). Chromosomal DNA was extracted from cells using Qiagen genomic-tip kits. PCR reactions of the seven housekeeping genes adhP, pheS, atr, glnA, sdhA, glcK and tkt were performed using primers described previously (Jones et al., 2003). The PCR products were then purified using Montage PCR centrifugal filter devices (Millipore). The amplicons were sequenced on both strands of DNA with internal nested primers using ABI Prism BigDye Terminator reaction mix. The reaction products were separated and detected with an ABI Prism 3700 DNA analyser (Applied Biosystems). A consensus sequence was generated using the MacVector program (Accelrys) for the seven gene fragments. This sequence was then uploaded to the GBS database at http://pubmlst. 
org/sagalactiae/ to obtain an allele designation. The combination of alleles at the seven loci provided a sequence type (ST) for each isolate (Jones et al., 2003; Maiden et al., 1998).

Molecular serotyping. PCRs were performed with new sets of primers (L. C. Madoff, unpublished results) along with primer combinations shown elsewhere to amplify regions of CPS locus thought to be specific for the nine serotypes (Kong et al., 2002a). DNA extracts from the prototype strains of the nine serotypes were used as positive controls. In addition, the $c f b$ (CAMP factor) gene was used as a control for GBS DNA.

Surface-protein genes. PCRs were performed with primer combinations shown elsewhere to amplify regions of the bca ( $\mathrm{C}$ alpha protein), bac (C beta protein), rib (Rib protein), alp1 (C alpha-like protein) and alp3 (C alpha-like protein) genes (Kong et al., 2002b). In addition, the $c f b$ gene was used as a control for GBS DNA. DNA from the prototype strains was used as a positive control for the presence of the surface-protein genes.

CPS locus sequencing. All eight NT isolates plus the four serotype $\mathrm{V}$ clinical isolates were sequenced for polymorphisms in the CPS locus. The 18 genes (SAG1158-SAG1175) found in the CPS locus were amplified by PCR (Takara LA PCR kit, Chemicon International) using standard conditions, and the resulting amplicons were treated with shrimp alkaline phosphatase (Amersham Biosciences) and exonuclease I (Amersham Biosciences). The purified PCR products were then sequenced on both strands using the BigDye terminator cycle sequencing kit (Applied Biosystems) according to standard protocols. A total of 80 sequencing primers were used to cover the entire CPS locus at $500 \mathrm{bp}$ intervals. For strains B2 and $\mathrm{B} 3$, strain-specific primers were designed to generate sequence data in regions where initial primers did not anneal. The sequencing reactions were run on 3730XL automated DNA sequencers (Applied Biosystems). The data from the sequencing instrument was assembled using TIGR assembler software (Pop \& Kosack, 2004; Sutton et al., 1995). The edited and assembled sequence was then compared with the sequence from strain 2603V/R deposited in GenBank (accession no. AE009948) using MacVector software.

\section{RESULTS}

\section{Immunoprecipitin reactions}

Sera from rabbits immunized with GBS isolates A1 and A2 reacted with $\mathrm{HCl}$ extracts from isolates $\mathrm{A} 1, \mathrm{~A} 2, \mathrm{~A} 3$ and $\mathrm{A} 4$, but not that from isolates B1, B2, B3 and B4 (Fig. 1). In addition, concentrated $\mathrm{HCl}$ extracts from isolates $\mathrm{A} 1-\mathrm{A} 4$, but not isolates B1-B4, reacted, albeit weakly, with type $\mathrm{V}$ CPS-specific antibody. These data suggest that isolates A1-A4 were atypical type $\mathrm{V}$, whereas isolates B1-B4 were nontypable. All eight isolates expressed R1 and R4 surfacelocalized proteins, as determined by double-immunodiffusion reactions with specific antisera (Flores \& Ferrieri, 1989). The results suggested that A1-A4 isolates were poorly encapsulated or had a modified type V CPS, whereas the NT isolates B1-B4 were acapsular, expressed an altered capsule, or had a small amount of CPS that was not detectable in a double-immunodiffusion reaction.

\section{Inhibition ELISA}

An inhibition ELISA was performed to determine the relative amounts of type V CPS produced by each isolate. In this
(A)

IA IIA

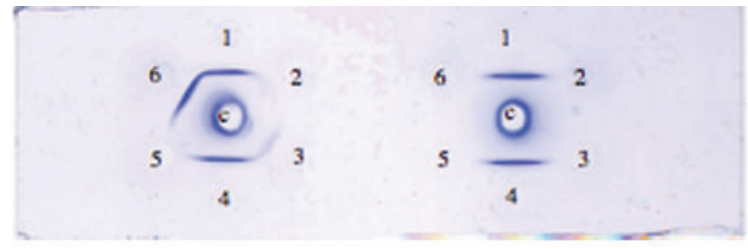

(B)

IB

IIB

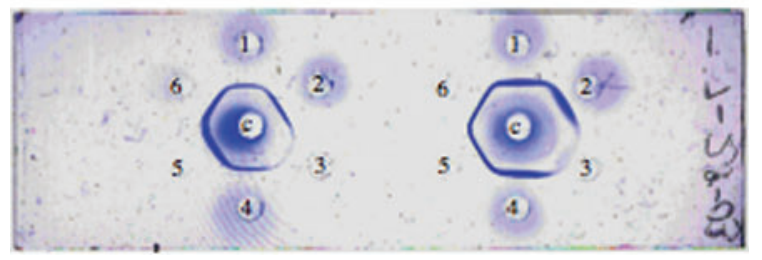

Fig. 1. Double-immunodiffusion reactions with rabbit antiserum produced against the prototype serotype $\mathrm{V}$ isolate (A) and reactions of atypical serotype $V$ isolates with antisera from rabbit 41 and rabbit 43 (B). In panels IA and IIA, the central well, $c$, contains antiserum raised against the prototype serotype $\mathrm{V}$ isolate. The peripheral six wells in panel IA contain $4 \times$ concentrated $\mathrm{HCl}$ extracts from the following isolates: 1, prototype $\mathrm{V}$; 2, A1; 3, A2; 4, prototype V; 5, A3; 6, A4. Panel IIA contains $4 \times$ concentrated $\mathrm{HCl}$ extracts from the following isolates: 1 , prototype $\mathrm{V} ; 2$, B1; 3, B2; 4, prototype V; 5, B3; 6, B4. In panel (B), the central well, $c$, contains serum from rabbit 41 containing antibodies raised against isolate $\mathrm{A} 1$ (IB) and from rabbit 43 containing antibodies raised against isolate A2 (IIB). The peripheral six wells in panel IB contain $5 \times$ concentrated $\mathrm{HCl}$ extracts from the following isolates: $1, \mathrm{~A} 1 ; 2, \mathrm{~A} 2 ; 3, \mathrm{~A} 3 ; 4$, $\mathrm{A} 1 ; 5$, prototype $\mathrm{V} ; 6, \mathrm{~A} 4$. The peripheral six wells in panel IIB contain $5 \times$ concentrated $\mathrm{HCl}$ extracts from the following isolates: 1, A2; 2, A1; 3, A3; 4, A2; 5, prototype V; 6, A4. The prototype serotype $\mathrm{V}$ extracts in all panels are unconcentrated.

assay, 0.03-0.05 $\mathrm{g} \mathrm{ml}^{-1}$ of purified type V CPS inhibited binding of type V CPS-specific antibody by $60 \%$. The concentration of type V CPS in the mutanolysin extracts was approximately $1.0 \mu \mathrm{g} \mathrm{ml}^{-1}$ for isolates $\mathrm{A} 1, \mathrm{~A} 2$ and $\mathrm{A} 3$, and $73 \mu \mathrm{g} \mathrm{ml}^{-1}$ for isolate A4. The relatively high amount of type V CPS expressed by isolate A4, as measured by inhibition ELISA, is consistent with the strong immunoprecipitin reaction seen in Fig. 1, panel IA. In contrast, extracts prepared from isolates B1-B4 each contained $<0.05 \mu \mathrm{g} \mathrm{ml}^{-1}$ of type V CPS.

\section{Clonality of isolates}

All eight isolates expressed R1, R4 proteins, and their PFGE band profile patterns showed that they were all similar and belonged to DNA profile group 4 (Fig. 2). This banding pattern was similar to that of a prototype V/R1, R4 isolate when matched with the PFGE database. Three of these isolates (B2-B4) had a one-band difference and were assigned to profile group $4 \mathrm{a}$. 


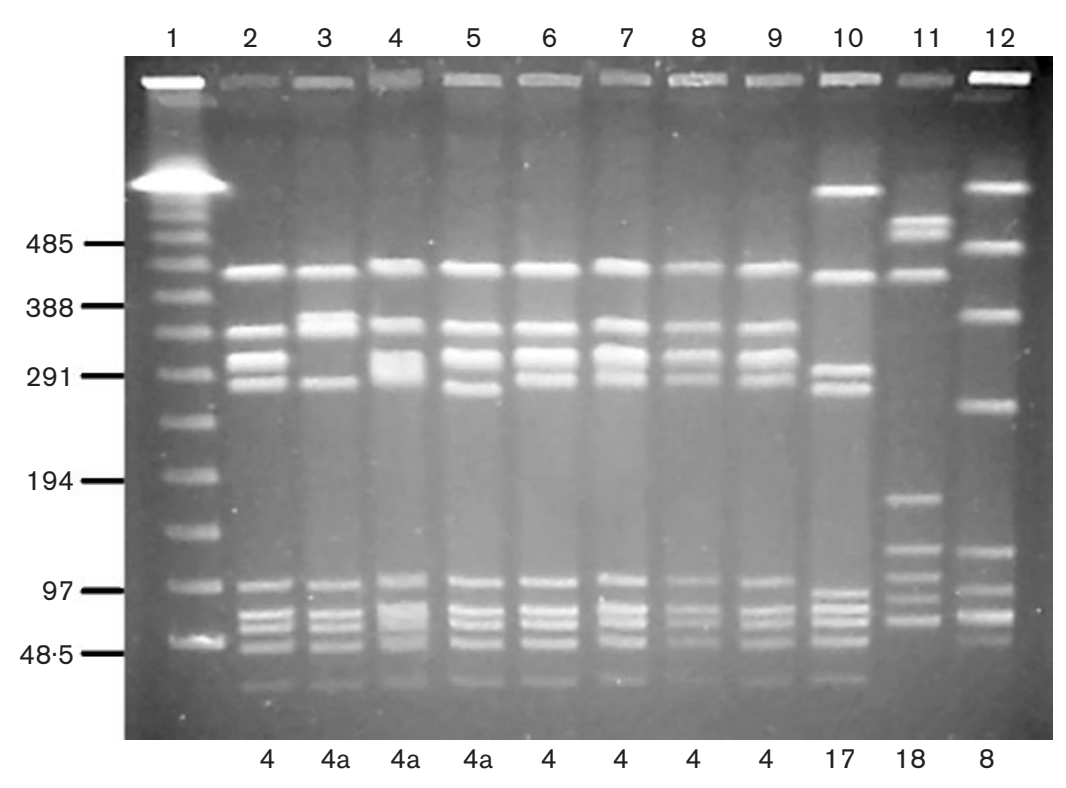

Fig. 2. Smal macrorestriction analysis by PFGE of the eight isolates. Numbers at the top of the gel are lane designations. Lane 1, lambda DNA marker with size in kb shown on left. Lanes (the protein profile of each isolate is shown after the CPS designation in parentheses): 2-5, isolates B1-B4 (NT/ $\mathrm{R} 1, \mathrm{R} 4) ;$ 6, A1 (V/R1, R4); 7, A3 (V/R1, R4); 8, A4 (V/R1, R4); 9, A2 (V/R1, R4); 10, prototype VII (none); 11, Denmark VII/ $\mathrm{c}(\alpha+\beta) ; 12$, PFGE control $\mathrm{lb} / \mathrm{c}(\alpha+\beta)$. The restriction profile number of each isolate is shown at the bottom of the gel.
An MLST assay was performed on all eight isolates to determine if the strains could be further distinguished genotypically (Maiden et al., 1998; Urwin \& Maiden, 2003). Isolate A1 had a new adhP allele, and hence a new ST was allocated (Table 1). The other seven isolates (A2-A4, B1B4) were all ST-1. These molecular typing results suggest that these eight isolates are genotypically similar.

\section{Molecular serotyping}

To gain further insight into the genetic makeup of these eight isolates, we performed molecular serotyping to identify the presence of CPS genes. All eight isolates had a positive PCR band for the $c f b$ gene (which encodes the CAMP factor) and type $\mathrm{V}$-specific ( $c p s O$ ) CPS gene. No PCR bands were detected for the other serotype-specific $c p s$ genes.

\section{Surface-protein genes}

Previous studies (Ferrieri \& Flores, 1997; Kong et al., 2002b) have shown strong associations between capsule serotypes and surface-protein genes. All eight isolates were found to have alp3, which is significantly associated with GBS type V (Kong et al., 2002a).

\section{CPS locus sequencing}

About $17 \cdot 7 \mathrm{~kb}$ of chromosomal DNA from each of the eight isolates was sequenced for polymorphisms in the CPS genes. Four additional serotype $\mathrm{V}$ isolates were sequenced to identify the diversity of polymorphisms in the cps locus and also to serve as a control sequence for interpretation of the sequence data from the atypical V and NT/R1, R4 isolates. The data from the sequencing reactions were used to build a contig and were then compared with the published $2603 \mathrm{~V} / \mathrm{R}$

Table 1. Immunologic and genetic analysis of the eight isolates

Type V CPS expression was determined by inhibition ELISA. Isolate A1 had a novel adhP allele designated 38, and its ST is a single-locus variant of ST-1.

\begin{tabular}{|c|c|c|c|c|c|c|c|}
\hline Isolate & $\begin{array}{c}\text { Accession } \\
\text { no. }\end{array}$ & $\begin{array}{c}\text { Type V CPS } \\
\left(\mu \mathrm{g} \mathrm{ml}^{-1}\right)\end{array}$ & $\begin{array}{c}\text { CPS/protein } \\
\text { profile }\end{array}$ & $\begin{array}{l}\text { PFGE } \\
\text { profile }\end{array}$ & MLST & $\begin{array}{l}\text { Molecular } \\
\text { serotype }\end{array}$ & $\begin{array}{c}\text { Protein } \\
\text { genes }\end{array}$ \\
\hline A1 & DQ359711 & $\sim 1$ & $\mathrm{~V} / \mathrm{R} 1, \mathrm{R} 4$ & 4 & 173 & $\operatorname{cps} O$ & alp3 \\
\hline A2 & DQ359710 & $\sim 1$ & V/R1, R4 & 4 & 1 & $\operatorname{cps} O$ & alp3 \\
\hline A3 & DQ359713 & $\sim 1$ & V/R1, R4 & 4 & 1 & $\operatorname{cps} O$ & alp3 \\
\hline A4 & DQ359707 & 73 & $\mathrm{~V} / \mathrm{R} 1, \mathrm{R} 4$ & 4 & 1 & $\operatorname{cps} O$ & alp3 \\
\hline B1 & DQ359709 & $<0.05$ & NT/R1, R4 & 4 & 1 & $\operatorname{cps} O$ & alp3 \\
\hline B2 & DQ359714 & $<0.05$ & NT/R1, R4 & $4 a$ & 1 & $\operatorname{cps} O$ & alp3 \\
\hline B3 & DQ359712 & $<0.05$ & NT/R1, R4 & $4 \mathrm{a}$ & 1 & $\operatorname{cps} O$ & alp3 \\
\hline B4 & DQ359708 & $<0.05$ & NT/R1, R4 & $4 \mathrm{a}$ & 1 & $\operatorname{cps} O$ & alp3 \\
\hline
\end{tabular}


genome sequence. Sequencing results for the four atypical $\mathrm{V}$ isolates (A1-A4) and the nonserotypable isolates (B1-B3) indicated that all the genes (SAG1158-SAG1175) were present without major deletions or insertions.

Isolate B4 had an $861 \mathrm{bp}$ insert at the third base of codon 373 in $\operatorname{cps} E$ (Fig. 3). This insert was identified as an insertion sequence, IS1381. The insertion sequence contained a $20 \mathrm{bp}$ terminal inverted repeat. The transcriptional direction of the two ORFs encoding putative transposases in the insertion sequence was reversed compared with that of $c p s E$.

All the isolates were carefully scanned for single nucleotide polymorphisms at the CPS locus. The atypical V/R1, R4 isolates, as well as the NT/R1, R4 isolates, had 28 common polymorphisms distributed across 10 CPS genes (Table 2); 12 of these mutations were synonymous changes, 13 were nonsynonymous changes, two were insertion mutations, and one was a single substitution mutation in the $c p s D-c p s E$ intergenic region. In addition, each isolate (A1-A4, B1-B4) showed one to three unique mutations (Table 3 ). The 28 common polymorphisms found in the eight isolates were also found in the three control typable $\mathrm{V}$ isolates whose ST was ST-1, suggesting a strong linkage disequilibrium between the polymorphisms found in the cps locus and the ST of the isolates. Another typable V isolate with an ST-7 profile shared most of the polymorphisms with 2603V/R (ST-19) strain, except for two polymorphisms (Table 2). All 12 isolates, independent of ST, had a 9 bp insertion at codon 217 of $\operatorname{cps} D$.

\section{DISCUSSION}

In the course of routine characterization of clinical GBS isolates, we identified eight strains that expressed R1, R4 proteins and shared PFGE profiles with a GBS serotype V strain, but were nontypable. We tested the hypothesis that these isolates harboured genetic changes in the GBS cps locus that result in an NT phenotype. These isolates were epidemiologically distinct and were NT by the routine double-immunodiffusion typing assay in agarose. Isolates A1-A4 gave a very weak reaction of identity with type $\mathrm{V}$ antiserum when their $\mathrm{HCl}$ extracts were concentrated fivefold, whereas isolates B1-B4 gave no reaction of identity even with concentrated extracts. This finding suggested that isolates A1-A4 were micro-encapsulated or had a modified type V CPS, and that isolates B1-B4 were acapsular or expressed very low amounts of type V CPS. It is also plausible that a novel serotype could exist among these latter isolates.

PFGE showed that all eight isolates had a profile similar to that of a GBS type $\mathrm{V}$ containing R1 and R4 proteins (Ferrieri et al., 1997). Previous studies have shown an association of isolates with specific CPS serotypes with certain protein profiles, e.g. alpha $\mathrm{C}$ protein with type Ia, alpha and beta $\mathrm{C}$ proteins with type Ib, Rib protein with type III, and R1, R4 proteins with type V (Ferrieri \& Flores, 1997; Flores \& Ferrieri, 1989; Kong et al., 2002b). Serotype V isolates have been found to fall into a limited number of profile groups, and serotype $\mathrm{V}$ isolates producing R1, R4 proteins tend to belong to profile group 4. Also, NT isolates with the R1, R4 protein profile tend to belong to PFGE group 4, suggesting that there is restricted genetic diversity among isolates producing R1, R4 proteins (Ferrieri et al., 1997). The PFGE profile group 4 is identical to PFGE subtype O described elsewhere (Elliott et al., 1998). The recent increase in the recovery of isolates with the NT/R1, R4 profile from patients may indicate a periodic shift of this clonal complex with improved genetic fitness. This periodic shift may also account for the observed restriction in genetic variation among NT/R1, R4 isolates. Future surveillance data will assess the extent of clonal divergence that may arise from this group of isolates. All eight isolates cluster into a single clonal group and belong to the ST-1 complex, which includes the newly identified ST-173 (isolate A1), a single-locus variant of ST-1.

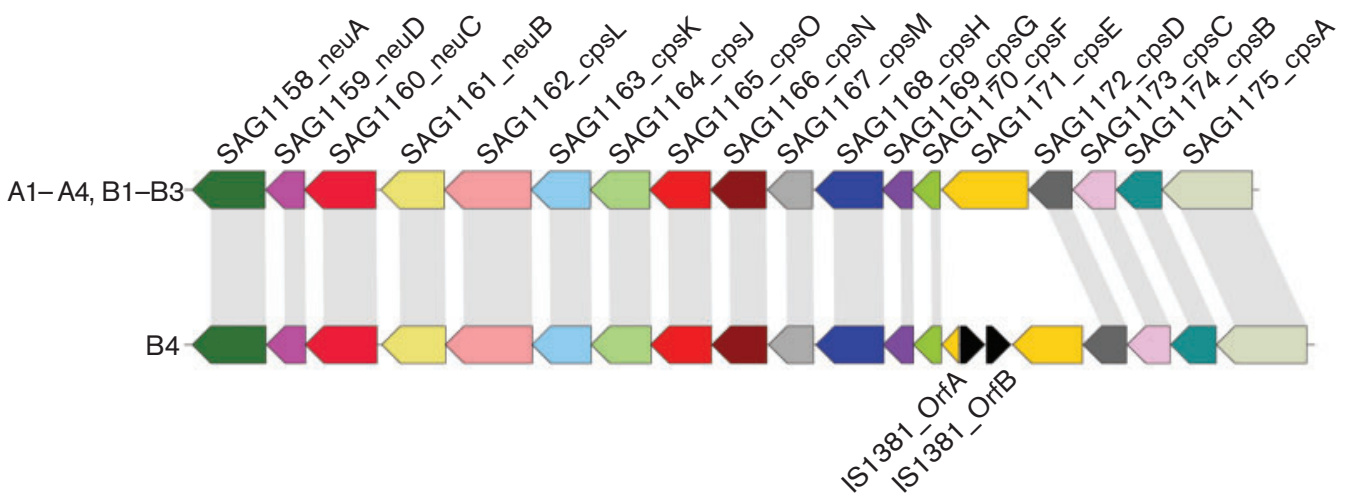

Fig. 3. Schematic of the cps genes sequenced. Isolate B4 has an IS1381 insert with two ORFs encoding transposases oriented in a direction opposite to the cps operon transcript. The DNA-sequenced regions of the eight isolates have been deposited in GenBank with accession numbers DQ359707-DQ359714. 
Table 2. Mutations common among the isolates and the relationship between MLST and cps locus polymorphisms

Isolates A2-A4 and B1-B4 were ST-1. Isolate A1 was ST-173, a single-locus variant of ST-1. Three additional serotype V isolates of ST-1 and a fourth isolate of ST-7 were sequenced. The isolate with ST-7 shared most of the polymorphisms with the 2603V/R strain, except for the polymorphisms in the two genes denoted by an asterisk. The identification of nucleotide and corresponding amino acid changes was based on the 2603V/R genome sequence. All 12 isolates had the 9 bp insert in $c p s D$. AA, single-letter amino acid designation; ups, upstream nucleotide sequence from the start site of the gene.

\begin{tabular}{|c|c|c|c|c|c|}
\hline \multirow[t]{2}{*}{ Gene } & \multirow[t]{2}{*}{ Codon } & \multicolumn{2}{|c|}{ Sequence } & \multicolumn{2}{|c|}{ AA } \\
\hline & & $\begin{array}{c}2603 \mathrm{~V} / \mathrm{R} \\
\text { ST-19 }\end{array}$ & $\begin{array}{c}\text { A1-B4 ST-1, } \\
\text { ST-173 }\end{array}$ & $2603 \mathrm{~V} / \mathrm{R}$ & A1-B4 \\
\hline \multirow[t]{5}{*}{ пеиА } & 367 & CTG & TTG & $\mathrm{L}$ & $\mathrm{L}$ \\
\hline & 261 & ACC & ATC & $\mathrm{T}$ & I \\
\hline & 194 & AGG & AAG & $\mathrm{R}$ & $\mathrm{K}$ \\
\hline & 189 & AGC & ATC & $S$ & I \\
\hline & 25 & TCT & GCA & S & A \\
\hline \multirow[t]{2}{*}{ neuD } & 180 & TCA & TCG & S & S \\
\hline & 128 & AAT & $\mathrm{AAC}$ & $\mathrm{N}$ & $\mathrm{N}$ \\
\hline$c p s L$ & 401 & ATT & GTT & I & $\mathrm{V}$ \\
\hline$c p s K^{\star}$ & 12 & TTA & CTA & $\mathrm{L}$ & $\mathrm{L}$ \\
\hline $\operatorname{cps} O$ & 53 & TTT & TTA & $\mathrm{F}$ & $\mathrm{L}$ \\
\hline \multirow[t]{2}{*}{$c p s E$} & 34 & AAT & AAC & $\mathrm{N}$ & $\mathrm{N}$ \\
\hline & 17 & ACA & ACC & $\mathrm{T}$ & $\mathrm{T}$ \\
\hline$c p s E$ ups & 10 & C & $\mathrm{T}$ & & \\
\hline \multirow[t]{4}{*}{$c p s D^{\star}$} & 217 & GAT & 9 bp insert & & \\
\hline & 176 & ACC & $\mathrm{ACT}$ & $\mathrm{T}$ & $\mathrm{T}$ \\
\hline & 52 & GCT & ACT & A & $\mathrm{T}$ \\
\hline & 43 & GTT & TTT & $\mathrm{V}$ & $\mathrm{F}$ \\
\hline \multirow[t]{2}{*}{$c p s C$} & 110 & TTG & CTG & $\mathrm{L}$ & $\mathrm{L}$ \\
\hline & 33 & GCA & GCG & A & A \\
\hline \multirow[t]{2}{*}{$c p s B$} & 165 & TCC & TCT & $S$ & $\mathrm{~S}$ \\
\hline & 25 & TTA & TTG & $\mathrm{L}$ & $\mathrm{L}$ \\
\hline \multirow[t]{6}{*}{$c p s A$} & 421 & AAC & AAT & $\mathrm{N}$ & $\mathrm{N}$ \\
\hline & 181 & GAT & AAT & $\mathrm{D}$ & $\mathrm{N}$ \\
\hline & 179 & AGT & AAT & S & $\mathrm{N}$ \\
\hline & 158 & AAA & GAA & K & $\mathrm{E}$ \\
\hline & 64 & GTA & GCA & V & A \\
\hline & 8 & CAC & CAA & $\mathrm{H}$ & Q \\
\hline$c p s A$ ups & 84 & & A insert & & \\
\hline
\end{tabular}

GBS isolates of both human and bovine origin belong to the ST-1 complex (Bisharat et al., 2004). STs can be grouped into lineages or clonal complexes by the BURST program, and isolates of the ST-1 complex are grouped as BURST lineage 1 (Bisharat et al., 2004; Jones et al., 2003). The typing assays indicate that the four atypical V/R1, R4 isolates and the four NT/R1, R4 isolates are genetically similar, but that they differ in the amount of type V CPS produced and/or may have a modified type V CPS.

The cpsO gene in the cps locus specifically associated with serotype $\mathrm{V}$ was present in all eight isolates. Although the presence of $c p s O$ does not indicate whether the gene product is expressed, the expected size of the amplicon obtained (642 bp, data not shown) rules out large insertions or deletions in the gene fragment that could potentially result in an NT phenotype. This result was corroborated by the CPS locus sequencing data. PCR analysis of the surfaceprotein genes identified the presence of alp 3 in all eight isolates. Our results did not identify the rib gene in any of the eight isolates, although all of them produced R1, R4 proteins. This finding concurs with the recent observation that isolates co-expressing the $\mathrm{R} 1$ and $\mathrm{R} 4$ proteins show a negative reaction in both PCR and Southern hybridization assays with an $r 4$ gene probe (Smith et al., 2004). The strong association between the presence of alp 3 and the coexpression of R1, R4 proteins suggests that alp 3 encodes a protein that reacts immunologically with both R1 and R4 antisera. Recent studies involving nucleotide and amino acid sequencing of the $\mathrm{R} 4$ protein indicate that the proteins 
Table 3. Mutations unique to each isolate

The nucleotide and amino acid changes in the isolates were based on the genome sequence of the $2603 \mathrm{~V} / \mathrm{R}$ strain. Isolate B4 had an $861 \mathrm{bp}$ insert at the third base of codon 373 in cpsE. This insert was identical to IS1381. AA, single letter amino acid designation; STOP, termination mutation; del, deletion of the nucleotide.

\begin{tabular}{|c|c|c|c|c|c|c|}
\hline \multirow[t]{2}{*}{ Isolate } & \multirow[t]{2}{*}{ Gene } & \multirow[t]{2}{*}{ Codon } & \multicolumn{2}{|c|}{ Sequence } & \multicolumn{2}{|c|}{ AA } \\
\hline & & & $2603 \mathrm{~V} / \mathrm{R}$ & Isolate & $2603 \mathrm{~V} / \mathrm{R}$ & Isolate \\
\hline \multirow[t]{2}{*}{ A1 } & $\operatorname{cps} G$ & 103 & CAT & TAT & $\mathrm{H}$ & $\mathrm{Y}$ \\
\hline & $\operatorname{cps} A$ & 82 & TTA & TTT & $\mathrm{L}$ & $\mathrm{F}$ \\
\hline \multirow[t]{2}{*}{ A2 } & $\operatorname{cps} G$ & 84 & GGA & A del & & \\
\hline & $\operatorname{cps} A$ & 95 & GGA & GGC & G & G \\
\hline \multirow[t]{3}{*}{ A3 } & $\operatorname{cps} G$ & 84 & GGA & A del & & \\
\hline & $\operatorname{cps} A$ & 463 & TAT & AAT & $\mathrm{Y}$ & $\mathrm{N}$ \\
\hline & & 412 & TCC & TCA & $S$ & $S$ \\
\hline A4 & $c p s M$ & 82 & GAT & GGT & $\mathrm{D}$ & G \\
\hline \multirow[t]{3}{*}{ B1 } & cpsJ & 178 & CCA & CTA & $\mathrm{P}$ & $\mathrm{L}$ \\
\hline & $\operatorname{cps} H$ & 269 & GGA & TGA & G & STOP \\
\hline & $c p s F$ & 12 & CAT & TAT & $\mathrm{H}$ & $\mathrm{Y}$ \\
\hline B2 & $c p s E$ & 362 & CGA & TCA & $\mathrm{R}$ & $\mathrm{S}$ \\
\hline \multirow[t]{2}{*}{ B3 } & $\operatorname{cps} G$ & 84 & GGA & A del & & \\
\hline & $\operatorname{cps} A$ & 466 & TCA & TTA & S & $\mathrm{L}$ \\
\hline B4 & $c p s E$ & 373 & TAT & $\begin{array}{r}861 \text { bp } \\
\text { insert }\end{array}$ & & \\
\hline
\end{tabular}

R4 and Rib are identical and encoded by the r4/rib gene (Smith et al., 2004). The gene that encodes the R1 protein has not been identified, and further study of the R1 and Alp family of proteins at the genetic level is warranted.

All 18 genes in the CPS locus were sequenced to find the genetic changes that would explain the phenotypic differences between the four atypical and the four NT isolates. Except for isolate B4, no major insertions or deletions were found in the isolates. Isolate B4 had an IS1381 insertion in the $\mathrm{C}$ terminus of cpsE. Originally identified in a Streptococcus pneumoniae R6 strain (Sanchez-Beato et al., 1997), IS1381 has been reported in GBS isolates of both human and bovine origin (Dmitriev et al., 2004; Shakleina et al., 2004; Tamura et al., 2000), although this is the first observation of the disruption by IS 1381 of a gene in the GBS cps locus. cpsE is thought to encode a glycosyltransferase in type Ia GBS and is proposed to have a role as the initiating enzyme in the biosynthesis of polysaccharide repeating units (Cieslewicz et al., 2001). Indeed, a cpsE knockout mutant in a serotype III strain has reduced CPS in both cell wall and protoplast fractions when compared with the wild-type parent strain (Chaffin et al., 2005). This finding is consistent with the reduced or disrupted expression of CPS due to apparent loss of the function of glycosyltransferase by isolate B4. Sequencing analysis also identified a 9 bp repetitive sequence in the $\mathrm{C}$ terminus of $c p s D$. All isolates used in this study, except for the $2603 \mathrm{~V} / \mathrm{R}$ isolate, had this repetitive sequence. This finding extends and corroborates the finding elsewhere
(Kong et al., 2002a) that all serotype $\mathrm{V}$ isolates have this repetitive sequence.

Sequencing analysis also showed the distribution of 28 polymorphisms across 10 CPS genes found in common in all eight isolates. The three typable isolates with the ST-1 profile (BURST lineage 1) had the same 28 polymorphisms, suggesting a linkage disequilibrium between the ST and the polymorphisms, and indicative of the clonal structure of these isolates. Furthermore, another typable isolate with ST-7 (BURST lineage 3) and a 2603V/R isolate (single-locus variant of ST-19, BURST lineage 6) had different sets of polymorphisms (Jones et al., 2003). The presence of these common sets of polymorphisms in both typable and NT isolates suggests that these polymorphisms are not involved in the NT phenotype.

In addition to the 28 common polymorphisms seen, one to three unique mutations were observed in seven of the eight isolates. Other than the IS1381 insertion, no unique singlenucleotide polymorphisms were found in isolate B4. Isolate B1 had a termination mutation in $c p s H$, a gene known to encode a polymerase in both serotypes Ia and III (Cieslewicz et al., 2001). This isolate also had a nonsynonymous mutation in two other genes, $c p s J$ and $c p s F$, whose products, CpsJ and $\mathrm{CpsF}$, are annotated to be a glycosyltransferase and a polysaccharide biosynthetic protein, respectively, in the sequenced genome of 2603V/R (Tettelin et al., 2002). A combination of these three mutations may account for the NT phenotype in this isolate. Four isolates (A1-A3, B3) had two mutations, one each in the $\operatorname{cps} G$ and $\operatorname{cps} A$ genes. cpsA is thought to encode a transcriptional regulator (Cieslewicz et al., 2001), and $\operatorname{cps} G$ is thought to encode a $\beta$-1,4-galactose transferase in both serotypes Ia and III (Cieslewicz et al., 2005). Three of the isolates (A2, A3 and B3) had a singlenucleotide deletion in codon 84 of $\operatorname{cps} G$, resulting in a frame-shift mutation that potentially results in loss of function of this glycosyltransferase. This truncation mutation, along with the other nonsynonymous changes found, may account for the NT phenotype in these isolates. Isolates A4 and B2 have a single nonsynonymous substitution in the $c p s M$ and $c p s E$ genes, respectively.

In conclusion, we have identified new genetic correlates for the NT phenotype in GBS. Knowledge of the composition and function of the various cps genes in different serotypes is warranted, as it provides insight into the dynamics of capsule biosynthesis, surface-protein expression, and the evolution of GBS serotypes.

\section{ACKNOWLEDGEMENTS}

This work was supported by NIH-NIAID contracts AI-25495 and AI38424. We thank Atul K. Johri, Vilas Patwardhan and Meghan Gilmore for technical assistance, and Dennis L. Kasper for advice and guidance. The contents of this publication do not necessarily reflect the views or policies of the Department of Health and Human Service, nor does the mention of trade names, commercial products or organizations imply endorsements by the US Government. 


\section{REFERENCES}

Baker, C. J., Paoletti, L. C., Rench, M. A., Guttormsen, H. K., Edwards, M. S. \& Kasper, D. L. (2004). Immune response of healthy women to 2 different group B streptococcal type $\mathrm{V}$ capsular polysaccharideprotein conjugate vaccines. J Infect Dis 189, 1103-1112.

Benson, J. A. \& Ferrieri, P. (2001). Rapid pulsed-field gel electrophoresis method for group B Streptococcus isolates. J Clin Microbiol 39, 3006-3008.

Benson, J. A., Flores, A. E., Baker, C. J., Hillier, S. L. \& Ferrieri, P. (2002). Improved methods for typing nontypeable isolates of group B streptococci. Int J Med Microbiol 292, 37-42.

Bisharat, N., Crook, D. W., Leigh, J., Harding, R. M., Ward, P. N., Coffey, T. J., Maiden, M. C., Peto, T. \& Jones, N. (2004). Hyperinvasive neonatal group B Streptococcus has arisen from a bovine ancestor. J Clin Microbiol 42, 2161-2167.

Bliss, S. J., Manning, S. D., Tallman, P., Baker, C. J., Pearlman, M. D., Marrs, C. F. \& Foxman, B. (2002). Group B Streptococcus colonization in male and nonpregnant female university students: a crosssectional prevalence study. Clin Infect Dis 34, 184-190.

Blumberg, H. M., Stephens, D. S., Modansky, M., Erwin, M., Elliot, J., Facklam, R. R., Schuchat, A., Baughman, W. \& Farley, M. M. (1996). Invasive group $\mathrm{B}$ streptococcal disease: the emergence of serotype $\mathrm{V}$. J Infect Dis 173, 365-373.

Chaffin, D. O., Mentele, L. M. \& Rubens, C. E. (2005). Sialylation of group B streptococcal capsular polysaccharide is mediated by $c p s K$ and is required for optimal capsule polymerization and expression. J Bacteriol 187, 4615-4626.

Cieslewicz, M. J., Kasper, D. L., Wang, Y. \& Wessels, M. R. (2001). Functional analysis in type Ia group B Streptococcus of a cluster of genes involved in extracellular polysaccharide production by diverse species of streptococci. J Biol Chem 276, 139-146.

Cieslewicz, M. J., Chaffin, D., Glusman, G., Kasper, D., Madan, A., Rodrigues, S., Fahey, J., Wessels, M. R. \& Rubens, C. E. (2005). Structural and genetic diversity of group B streptococcus capsular polysaccharides. Infect Immun 73, 3096-3103.

Davies, H. D., Jones, N., Whittam, T. S., Elsayed, S., Bisharat, N. \& Baker, C. J. (2004). Multilocus sequence typing of serotype III group B Streptococcus and correlation with pathogenic potential. J Infect Dis 189, 1097-1102.

Dmitriev, A., Shen, A., Shen, X. \& Yang, Y. (2004). ISSa4-based differentiation of Streptococcus agalactiae strains and identification of multiple target sites for ISSa4 insertions. J Bacteriol 186, 11061109.

Elliott, J. A., Farmer, K. D. \& Facklam, R. R. (1998). Sudden increase in isolation of group $\mathrm{B}$ streptococci, serotype $\mathrm{V}$, is not due to emergence of a new pulsed-field gel electrophoresis type. J Clin Microbiol 36, 2115-2116.

Farley, M. M. (2001). Group B streptococcal disease in nonpregnant adults. Clin Infect Dis 33, 556-561.

Fasola, E., Livdahl, C. \& Ferrieri, P. (1993). Molecular analysis of multiple isolates of the major serotypes of group B streptococci. J Clin Microbiol 31, 2616-2620.

Ferrieri, P. \& Flores, A. E. (1997). Surface protein expression in group B streptococcal invasive isolates. Adv Exp Med Biol 418, 635-637.

Ferrieri, P., Cho, D. S., Livdahl, C., Rubens, C. E. \& Flores, A. E. (1997). DNA restriction profiles of nontypable group B streptococcal clinical isolates. Adv Exp Med Biol 418, 343-346.

Flores, A. E. \& Ferrieri, P. (1989). Molecular species of R-protein antigens produced by clinical isolates of group B streptococci. J Clin Microbiol 27, 1050-1054.
Jones, N., Bohnsack, J. F., Takahashi, S. \& 9 other authors (2003). Multilocus sequence typing system for group B Streptococcus. J Clin Microbiol 41, 2530-2536.

Kong, F., Gowan, S., Martin, D., James, G. \& Gilbert, G. L. (2002a). Serotype identification of group B streptococci by PCR and sequencing. J Clin Microbiol 40, 216-226.

Kong, F., Gowan, S., Martin, D., James, G. \& Gilbert, G. L. (2002b). Molecular profiles of group B streptococcal surface protein antigen genes: relationship to molecular serotypes. J Clin Microbiol 40, 620-626.

Le Thomas-Bories, I., Fitoussi, F., Mariani-Kurkdjian, P., Raymond, J., Brahimi, N., Bidet, P., Lefranc, V. \& Bingen, E. (2001). Clonal relationship between U.S. and French serotype V group B Streptococcus isolates. J Clin Microbiol 39, 4526-4528.

Lindahl, G., Stalhammar-Carlemalm, M. \& Areschoug, T. (2005), Surface proteins of Streptococcus agalactiae and related proteins in other bacterial pathogens. Clin Microbiol Rev 18, 102-127.

Maiden, M. C., Bygraves, J. A., Feil, E. \& 10 other authors (1998). Multilocus sequence typing: a portable approach to the identification of clones within populations of pathogenic microorganisms. Proc Natl Acad Sci U S A 95, 3140-3145.

Maione, D., Margarit, I., Rinaudo, C. D. \& 24 other authors (2005). Identification of a universal Group B Streptococcus vaccine by multiple genome screen. Science 309, 148-150.

Palacios, G. C., Eskew, E. K., Solorzano, F. \& Mattingly, S. J. (1997). Decreased capacity for type-specific-antigen synthesis accounts for high prevalence of nontypeable strains of group B streptococci in Mexico. J Clin Microbiol 35, 2923-2926.

Paoletti, L. C. \& Kasper, D. L. (2003). Glycoconjugate vaccines to prevent group B streptococcal infections. Expert Opin Biol Ther 3, 975-984.

Pop, M. \& Kosack, D. (2004). Using the TIGR assembler in shotgun sequencing projects. Methods Mol Biol 255, 279-294.

Ramaswamy, S. V., Ferrieri, P., Madoff, L. C., Flores, A. E. \& Paoletti, L. C. (2004). Immunologic and genetic analysis of atypical serotype $V$ group B Streptococcus. In 44th Interscience Conference on Antimicrobial Agents and Chemotherapy, abstract D-1733. Washington, DC: American Society for Microbiology.

Sanchez-Beato, A. R., Garcia, E., Lopez, R. \& Garcia, J. L. (1997). Identification and characterization of IS1381, a new insertion sequence in Streptococcus pneumoniae. J Bacteriol 179, 2459-2463.

Sellin, M., Olofsson, C., Hakansson, S. \& Norgren, M. (2000). Genotyping of the capsule gene cluster (cps) in nontypeable group B streptococci reveals two major $c p s$ allelic variants of serotypes III and VII. J Clin Microbiol 38, 3420-3428.

Shakleina, E., Dmitriev, A., Tkacikova, L., Suvorov, A., Mikula, I. \& Totolian, A. (2004). Presence of insertion sequences (IS elements) in group B streptococci of bovine origin. Indian J Med Res 119, 242-246.

Slotved, H. C., Sauer, S. \& Konradsen, H. B. (2002). Falsenegative results in typing of group $\mathrm{B}$ streptococci by the standard Lancefield antigen extraction method. J Clin Microbiol 40, 18821883.

Smith, B. L., Flores, A., Dechaine, J., Krepela, J., Bergdall, A. \& Ferrieri, P. (2004). Gene encoding the group B streptococcal protein $\mathrm{R} 4$, its presence in clinical reference laboratory isolates \& R4 protein pepsin sensitivity. Indian J Med Res 119, 213-220.

Sutton, G. G., White, O., Adams, M. D. \& Kerlavage, A. R. (1995). TIGR Assembler: a new tool for assembling large shotgun sequencing projects. Genome Sci Technol 1, 9-19.

Tamura, G. S., Herndon, M., Przekwas, J., Rubens, C. E., Ferrieri, P. \& Hillier, S. L. (2000). Analysis of restriction fragment length 
polymorphisms of the insertion sequence IS1381 in group B streptococci. J Infect Dis 181, 364-368.

Tenover, F. C., Arbeit, R. D., Goering, R. V., Mickelsen, P. A., Murray, B. E., Persing, D. H. \& Swaminathan, B. (1995). Interpreting chromosomal DNA restriction patterns produced by pulsed-field gel electrophoresis: criteria for bacterial strain typing. J Clin Microbiol 33, 2233-2239.

Tettelin, H., Masignani, V., Cieslewicz, M. J. \& 40 other authors (2002). Complete genome sequence and comparative genomic analysis of an emerging human pathogen, serotype V Streptococcus agalactiae. Proc Natl Acad Sci U S A 99, 12391-12396.

Tettelin, H., Masignani, V., Cieslewicz, M. J. \& 43 other authors (2005). Genome analysis of multiple pathogenic isolates of Streptococcus agalactiae: implications for the microbial 'pan-genome'. Proc Natl Acad Sci U S A 102, 13950-13955.

Urwin, R. \& Maiden, M. C. (2003). Multi-locus sequence typing: a tool for global epidemiology. Trends Microbiol 11, 479-487. 